\title{
Factors affecting feed efficiency in dairy goats
}

\author{
Tadeu Silva de Oliveira1 ${ }^{1}$, Fernando de Paula Leonel ${ }^{2}$, Cássio José da \\ Silva $^{3}$, Danielle Ferreira Baffa ${ }^{1}$, José Carlos Pereira ${ }^{1}$, Joanis Tilemahos Zervoudakis ${ }^{4}$
}

\author{
${ }^{1}$ Universidade Federal de Viçosa, Viçosa, MG, Brasil. \\ 2 Universidade Federal de São João del-Rei, São João del-Rei, MG, Brasil. \\ ${ }^{3}$ Universidade de Brasília, Brasília, DF, Brasil. \\ ${ }^{4}$ Universidade Federal de Mato Grosso, Cuiabá, MT, Brasil.
}

\begin{abstract}
The objective of this study was to present some factors affecting feed efficiency in dairy goats. To develop our work, individual and average data from performance experiments with lactating goats were used. The following variables were evaluated: gross feed efficiency, adjusted feed efficiency, dry matter intake, milk-yield, 3.5\% fat-corrected milk yield, dry matter digestibility, dietary neutral detergent fiber content, different roughage-to-concentrate ratios and body weight. The statistical analyses involved the application of descriptive and dispersion measures besides Pearson's correlation coefficient and linear regression analysis. The analyzed variables were highly correlated with feed efficiency. The feed efficiency of lactating goats was affected by the milk fat correction, dry matter digestibility, dietary fiber content, proportion of roughage in the diet and body weight. Among these factors, standardization of the milk fat appeared to be the most efficient in correcting the feed efficiency in lactating goats. Correction of some of these factors implies greater precision in the measurement of feed efficiency.
\end{abstract}

Key Words: dry matter intake, goat, milk yield

\section{Introduction}

The transformation of food energy into products of animal origin, as in any other energy transformation system, is not devoid of losses since there is an efficiency by which the food energy is used for maintenance and production (Henrique et al., 2005). Animal feeding is the biggest factor responsible for the expenditures involved in milk production. Decreasing the cost with feeding depends upon improvements in the conversion of the feed to milk nutrients (Linn, 2006). Such conversion is also named feed efficiency (FE), which is defined as the relationship between the daily volume of produced milk $(\mathrm{kg})$ and the daily dry matter intake $(\mathrm{kg})$.

The pig, poultry and beef-cattle farming sectors have already applied this concept long ago, but only in the last decade was the use of FE introduced in the milk industry (St-Pierre, 2001; Hutjens, 2005; Linn, 2006). However, FE is highly variable across the dairy herds, and this has a considerable impact on the economic performance. Several factors may affect the FE in dairy herds, e.g. days

Received January 28, 2014 and accepted August 22, 2014

Corresponding author: tadeusilva@zootecnista.com.br

http://dx.doi.org/10.1590/S1516-35982014001000003

Copyright $@ 2014$ Sociedade Brasileira de Zootecnia. This is an Open Access article distributed under the terms of the Creative Commons Attribution Non-Commercial License, which permits unrestricted non-commercial use, distribution, and reproduction in any medium, provided the original work is properly cited. in milk, parity order, body weight, body condition score, rumen acidosis, genetics, reproduction, healthy status, milk fat correction, dry matter digestibility, thermal stress and addition of additives to the diet (Linn et al., 2009).

Furthermore, monitoring the FE has become not only an economic marker in dairy farming, but also an excellent environmental marker (Hutjens, 2010). The deposition of nutrients in the milk will increase as the feed efficiency is increased, which results in lower excretion of residues into the environment (Linn et al., 2009).

Even today studies conducted with dairy goats adopt feed efficiency calculated as the ratio between the milk volume produced per day $(\mathrm{kg})$ and the daily dry matter intake $(\mathrm{kg})$. In this scenario, the objective of this study was to present some factors affecting feed efficiency in lactating goats.

\section{Material and Methods}

For the development of this study, individual and average data from performance experiments with lactating goats were used.

The following variables were evaluated: gross feed efficiency, adjusted feed efficiency, dry matter intake, milkyield, 3.5\% fat-corrected milk yield, dry matter digestibility, dietary neutral detergent fiber (NDF) content, different roughage-to-concentrate ratios, and body weight. 
The dataset was obtained from nine studies, totaling 37 treatments and 183 experimental units (EU), compiled from theses and papers published in national and international journals (Table 1).

Three scientific articles (Oliveira Jr. et al., 2002; Zambom et al., 2005; Branco et al., 2011) were used to analyze the influence of $3.5 \%$-fat corrected milk yield on feed efficiency, with 14 treatments and 81 experimental units. Four studies were used for the dry matter digestibility, consisting of one doctoral thesis and three scientific articles (Silva, 2005; Fonseca et al., 2008; Zambom et al., 2008; Branco et al., 2011), totaling 16 treatments and 83 experimental units. For the NDF levels, three studies were used: one doctoral thesis and two scientific articles (Carvalho et al., 2006; Branco et al., 2011; Felisberto, 2011), totaling 14 treatments and 51 experimental units. For the roughage: concentrate ratio, two scientific articles were used (Silva et al., 1999; Zambom et al., 2005), with eight treatments and 38 experimental units. One doctoral thesis (Felisberto, 2011) was used for body weight, totaling four treatments and 16 experimental units.

In the studies in which milk was not corrected for 3.5\% fat, we used the equation described by Sklan et al. (1992): MY3.5\% $=(0.432+0.1625 \times \%$ milk fat $) \times$ milk yield, $\mathrm{kg} / \mathrm{d}$.

The gross feed efficiency (FE) and the adjusted feed efficiency were calculated using the following formulae:

$\mathrm{FE}=$ milk yield $(\mathrm{kg}) /$ dry matter intake $(\mathrm{kg})$;

Adjusted $\mathrm{FE}=3.5 \%$ fat-corrected milk yield $(\mathrm{kg}) /$ dry matter intake $(\mathrm{kg})$.

The statistical analyses involved the application of the basic descriptive measures to generate the profile of the dataset by the measurements of central tendency (mean and median) and dispersion (maximum, minimum, and standard error of the mean [SEM]) using PROC MEANS. Pearson's correlation coefficient was used to measure the intensity of the linear relationship between the feed efficiency and the other variables, according to procedure PROC CORR. Afterwards, linear regression analysis was performed via procedure PROC MIXED of SAS (Statistical Analysis System, version 9) software. However, because average daily gain (ADG) and dry matter intake (DMI) are variables of normal distribution, and because their division generates a Cauchy distribution variable (Mood et al., 1974), it is more appropriate to generate a normal distribution variable from the transformation of the two variables according to the descriptions of Box and Cox (1964). The following model was used:

$$
\mathrm{Y}_{i j}=\mu+\alpha_{i}+\beta_{j}+\mathrm{e}_{i j}
$$

in which $\mathrm{Y}_{i j}=$ measured value on the $j$-th variable in the $i$-th study; $\mu=$ overall mean; $\alpha_{i}=i$-th variable; $\beta_{j}=j$-th study and $\mathrm{e}_{i j}=$ random error.

\section{Results}

Overall, the total ranges of the different variables (Table 2) behaved satisfactorily given the objectives of the study, in which we used diets that varied from low to high quality.

The dry matter intake, dietary NDF content, roughageto-concentrate ratio and live weight had a negative correlation $(\mathrm{P}<0.05)$ with feed efficiency, indicating that increase in these variables inversely affect $\mathrm{FE}$, reducing it (Table 3). In contrast, milk yield, 3.5\% fat-corrected milk yield and dry matter digestibility positively affected $(\mathrm{P}<0.05) \mathrm{FE}$.

Table 1 - Characteristics of the database used for the calculations of feed efficiency

\begin{tabular}{|c|c|c|c|c|c|c|}
\hline Study & Author/Year & Published in & EU & DIM & NTreat & Treatments \\
\hline 1 & Felisberto, 2011 & Thesis - Universidade Federal de Viçosa & 16 & 60 & 4 & Levels of peNDF $(34,41,49,57 \%)$ \\
\hline 2 & Silva, 2005 & Thesis - Universidade Federal de Viçosa & 24 & 28 & 4 & $\begin{array}{c}\text { Control, soybean oil, soybeans, calcium salts of } \\
\text { long-chain fatty acids }\end{array}$ \\
\hline 3 & Zambom et al., 2008 & Revista Brasileira de Zootecnia & 18 & 60 & 3 & Levels of soybean hulls $(0,50,100 \%)$ \\
\hline 4 & Fonseca et al., 2008 & Arq. Bras. Med. Vet. Zootec. ${ }^{1}$ & 16 & UD & 4 & Levels of crude protein $(11.5,13.5,15.5,17.5)$ \\
\hline 7 & Silva et al., 1999 & Revista Brasileira de Zootecnia & 18 & 105 & 3 & Roughage-to-concentrate ratio $(38: 62,48: 52,58: 42)$ \\
\hline 8 & Zambom et al., 2005 & Revista Brasileira de Zootecnia & 20 & 60 & 5 & Roughage-to-concentrate ratio $(40: 60,50: 50,60: 40,70: 30)$ \\
\hline 9 & Oliveira Jr. et al., 2002 & Acta Scientiarum & 36 & 90 & 4 & $\begin{array}{l}\text { Levels of raw soybeans replacing soybean meal } \\
\qquad(0,7,14,21 \%)\end{array}$ \\
\hline
\end{tabular}

UD - unpublished data; EU - number of individual experimental units; DIM - days in milk; NTreat - number of treatments used in each study; peNDF - physically effective neutral detergent fiber.

${ }^{1}$ Arquivo Brasileiro de Medicina Veterinária e Zootecnia. 
Table 2 - Descriptive statistics for the analyzed variables

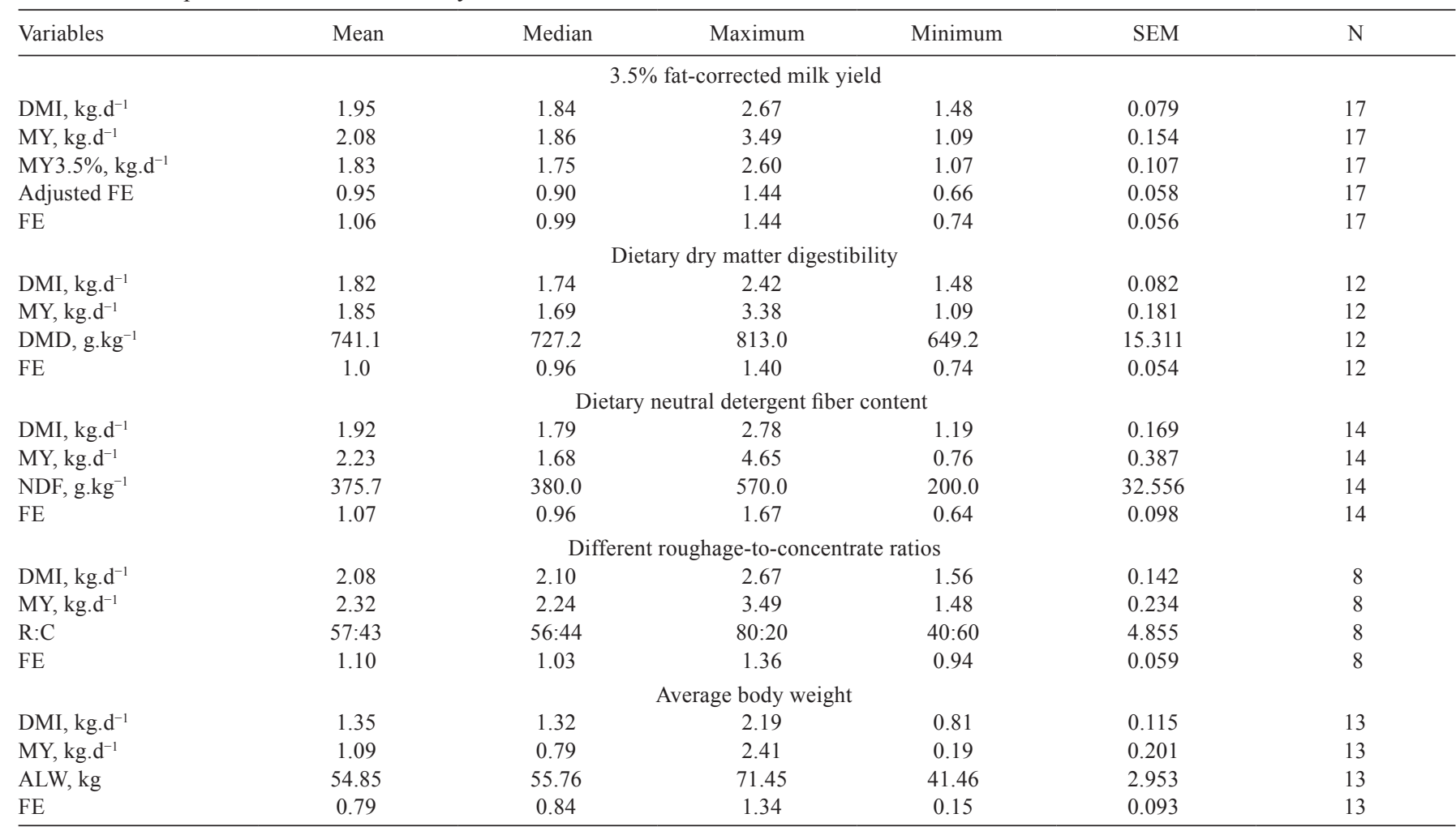

SEM - standard error of the mean; $\mathrm{N}$ - number of means used in each variable.

DMI - dry matter intake; MY - milk yield; MY3.5\% - 3.5\% fat-corrected milk yield; FE - feed efficiency; DMD - dry matter digestibility; NDF - neutral detergent fiber; $\mathrm{R}: \mathrm{C}$ - roughage-to-concentrate ratio; ALW - average live weight.

The fat-corrected milk yield presents a positive correlated (0.89) with FE. Feed efficiency increased by 0.061 points with every one-liter increase in milk yield (Figure 1).

In the present study we obtained a positive high correlation (0.834) (Table 3) between DMD and FE. Additionally, an increase of 10 percentage points in the DMD allowed for an increment of 0.024 points in FE (Figure 2).

The correlation between the NDF and FE was -0.87 (Table 3), confirming the negative effect of increasing the dietary fiber for lactating goats. Yet, an increase of 10 percentage points in the fiber content resulted in reduction of 0.001 point in FE (Figure 3).

Table 3 - Pearson's correlation coefficients and probability values of feed efficiency-dependant variables

\begin{tabular}{lcc}
\hline \multirow{2}{*}{ Variables } & \multicolumn{2}{c}{ Feed efficiency } \\
\cline { 2 - 3 } & Correlation coefficients & P-value \\
\hline Dry matter intake, kg.d & -0.41 & 0.008 \\
Milk yield, kg.d $\mathrm{d}^{-1}$ & 0.83 & $<0.0001$ \\
$3.5 \%$ fat-corrected milk yield, kg.d ${ }^{-1}$ & 0.89 & $<0.0001$ \\
Dry matter digestibility, g.kg & 0.83 & 0.004 \\
Dietary NDF content, g.kg & -0.87 & 0.002 \\
Roughage-to-concentrate ratio & -0.72 & 0.04 \\
Live weight, kg & -0.67 & 0.01 \\
\hline
\end{tabular}

NDF - neutral detergent fiber.
Feed efficiency reduced $(\mathrm{P}=0.02)$ as the proportion of roughage increased (Figure 4), and an elevation of 10 percentage point in this proportion of roughage generated a reduction of 0.002 point in $\mathrm{FE}$, which is linked to the low DM digestibility of the roughage in relation to the concentrate. The correlation between these variables was -0.72 (Table 3 ), due the negative effect of increase in the proportion of dietary roughage for lactating goats.

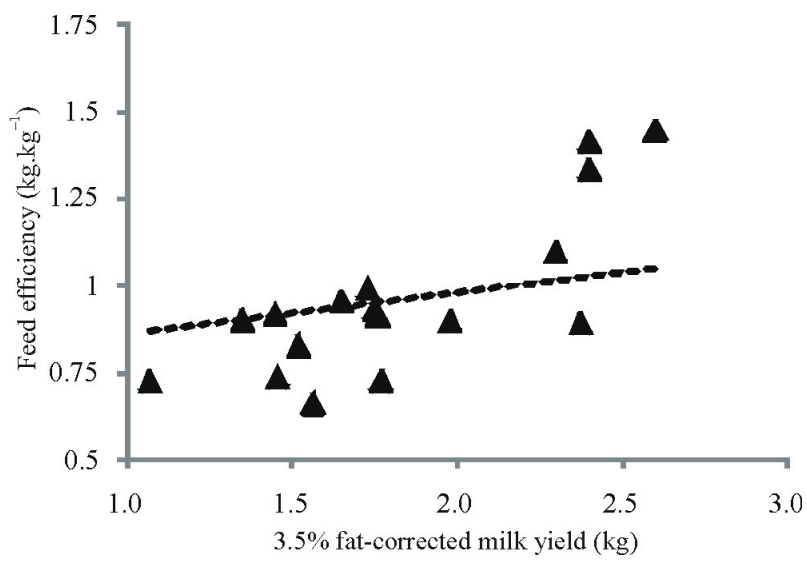

The estimated regression equation was: $\mathrm{FE}=0.2343 \pm 0.0030+0.061 \pm 0.0015 \times$ MY3.5\%; P = 0.0007; AICc $=-140.0 ; \mathrm{n}=17$.

AICc is Akaike's information criterion. Dashed line indicates the predicted value.

Figure 1 - Effect of 3.5\% fat-corrected milk yield (MY3.5\%) on the feed efficiency (FE) of lactating goats. 


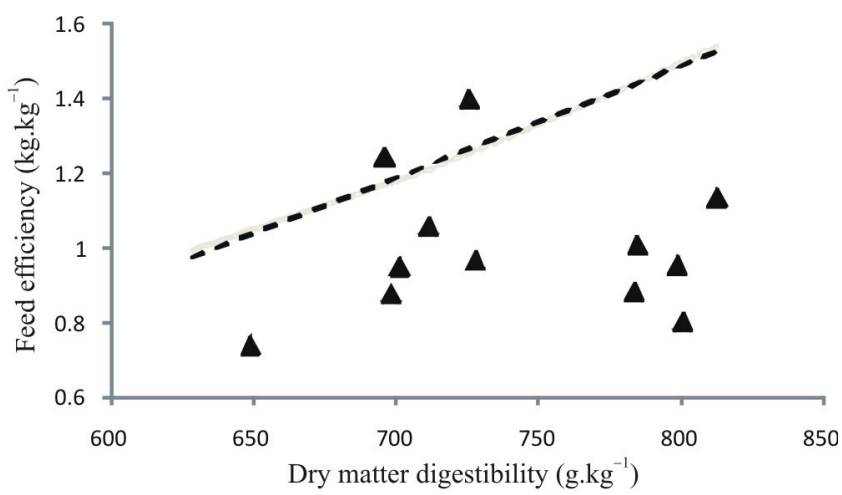

The estimated regression equation was: $\mathrm{FE}=-1.5064 \pm 1.3452+0.024 \pm 0.0012 \times$ DMD g. $\mathrm{kg}^{-1} ; \mathrm{P}=0.01 ; \mathrm{AICc}=1.60 ; \mathrm{n}=12$.

AICc is Akaike's information criterion. Dashed line indicates the predicted value.

Figure 2 - Effect of dry matter digestibility (DMD) on the feed efficiency (FE) of lactating goats.

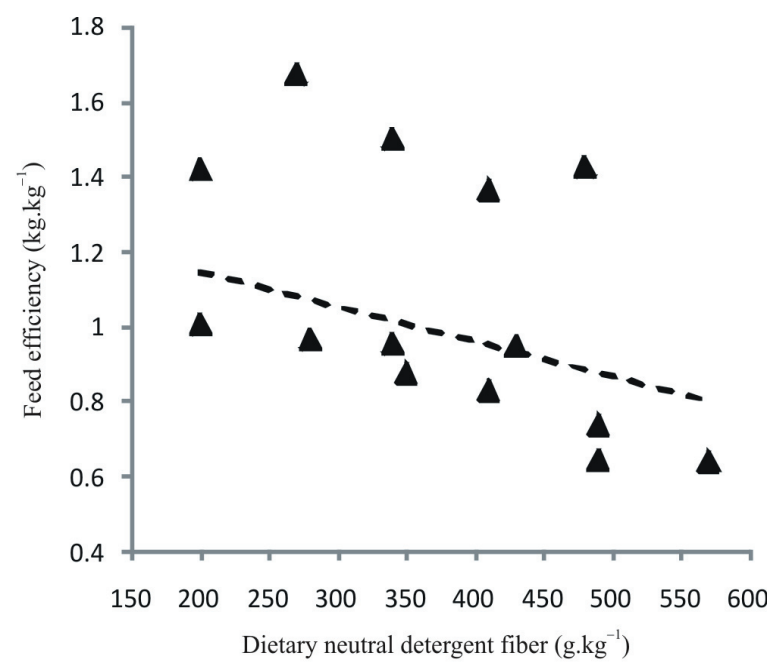

The estimated regression equation was: $\mathrm{FE}=0.4165 \pm 0.0702-0.001 \pm 0.0008 \times \mathrm{NDF}$ g. $\mathrm{kg}^{-1}$; $\mathrm{P}=0.01 ; \mathrm{AICc}=-47.1 ; \mathrm{n}=14$.

AICc is Akaike's information criterion. Dashed line indicates the predicted value.

Figure 3 - Effect of dietary neutral detergent fiber (NDF) content on the feed efficiency (FE) of lactating goats.

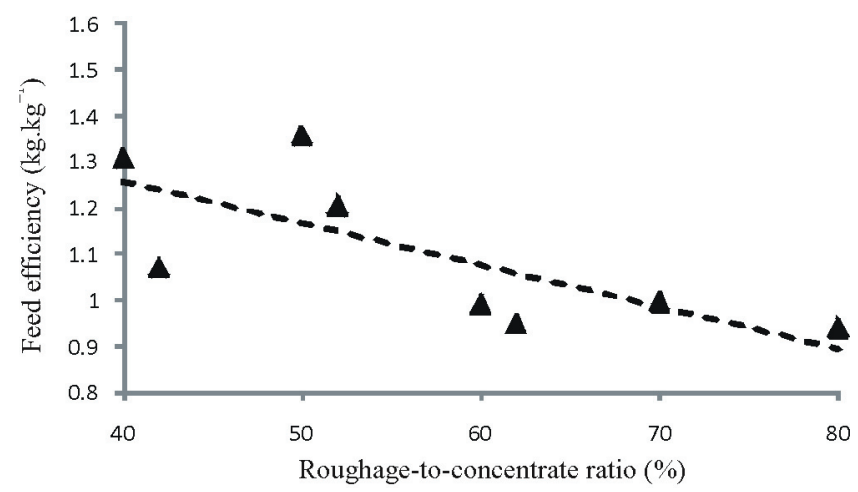

The estimated regression equation was: $\mathrm{FE}=0.0953 \pm 0.00008-0.002 \pm 0.0001 \times \mathrm{R}: \mathrm{C}$; $\mathrm{P}=0.02 ; \mathrm{AICc}=-95.5 ; \mathrm{n}=8$.

AICc is Akaike's information criterion. Dashed line indicates the predicted value.

Figure 4 - Effect of roughage-to-concentrate ratio (R:C) on the feed efficiency (FE) of lactating goats.

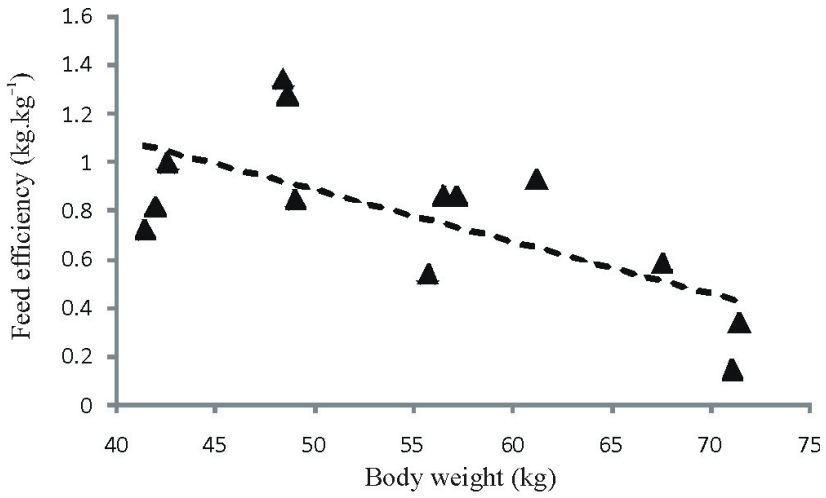

The estimated regression equation was: $\mathrm{FE}=1.5536 \pm 0.6505-0.0163 \pm 0.0116 \times \mathrm{BW}, \mathrm{kg}$; $\mathrm{P}=0.01 ; \mathrm{AICc}=7.5 ; \mathrm{n}=13$.

AICc is Akaike's information criterion. Dashed line indicates the predicted value.

Figure 5 - Effect of body weight (BW) on the feed efficiency (FE) of lactating goats.

Feed efficiency is reduced $(\mathrm{P}=0.01)$ as the goats gain weight, with a linear correlation of -0.67 (Table 3 ) between these variables. And an elevation of 10 percentage points in the body weight generated a reduction of 0.016 point in FE (Figure 5).

\section{Discussion}

Milk yield, 3.5\% fat-corrected milk yield and dry matter digestibility positively affected $(\mathrm{P}<0.05) \mathrm{FE}$, i.e., as the production and digestibility increased, the FE of the animals did likewise, which is in agreement with the results found by some authors (Linn et al., 2007; Socha et al., 2007; Linn et al., 2009).

Adopting only the milk yield to determine the FE and disregarding the fat content may be a problem, because the production of the milk fat has a high energy cost, which implies the need to normalize the fat or energy content of the milk so as to obtain a more precise measurement of the FE (Linn, 2006).

High-yield animals are more energetically efficient, since the most part of the ingested energy is diverted to the mammary gland for production of milk, in relation to maintenance (Linn et al., 2007). Using compiled data from fifteen studies with lactating cows of different breeds and under different dietary systems, Reis et al. (2013) observed that the FE of these animals increased as their fat-corrected milk yield was increased.

The behavior shown by this variable (Figure 1) corroborates the findings of Linn et al. (2007) and Reis et al. (2013), where the fat-corrected milk yield presents a positive, linear relationship with FE. However, another very important aspect is the dry matter intake, which in this 
study was negatively correlated (-0.41) with FE (Table 3), i.e., FE is reduced as DM intake increases. This suggests that in order to achieve greater FE, not only ingestion of dry matter but also of potentially digestible dry matter should be maximized; in other words, the qualitative potential of the feed directly affects FE.

The increased digestibility of the feeds implies greater availability of nutrients for production of milk; thus, FE improves as milk yield is increased (Figure 2). According to the NRC (2001), the digestibility of the diet reduces as the ingestion of total dry matter is elevated. Based on this premise, in the calculation to determine the energy content of the diet, a correction is made for the total digestible nutrient (TDN) content of the diet according to the increase in the level of dry matter intake.

Gabel et al. (2003) observed that lactating cows fed the same diet, but with 1.4, 2.7 and 4.6 times their energy requirements for maintenance, showed a decrease in DM digestibility $(74.8,72.3$ and $67.2 \%$, respectively) only with increase in dietary DM intake. Hence, the digestibility of the DM or other nutrients, when measured as percentage of the total intake, reduces as the DM intake is increased.

However, for Casper et al. (2004), it must be emphasized that goats, cows and sheep require quantities of digestible nutrients to produce milk, according to their nutritional requirements. Although the digestibility as percentage in the diet reduces as the DM intake increases, the amount of available digestible nutrients increases as the ingestion of feed by these animals is increased. Thus, maximization in dry matter intake and nutrient digestibility will result in greater milk yield, and consequently higher FE. For Casper et al. (2004) and Linn et al. (2007), the DMD is positively correlated with the FE.

The formulation of diets having NDF as basis was recommended by Mertens (1994) to maintain the ruminal fermentation steady and avoid reduction in the milk fat content. The NRC (2001) recommends at least $25 \%$ fiber in the diet, measured as neutral detergent fiber, and the other $75 \%$ of the diet should consist of forages.

Diets with high NDF contents tend to reduce the DM intake of animals because the fiber is the slow and incompletely digestible fraction of the feeds, and has a filling effect in the gastrointestinal tract of animals (Mertens, 1997). Because of its slow fractional degradation rate and low passage rate through the rumen environment, thus limiting the feed intake, the fiber content of the diet is inversely related to the net energy level. Reduction in the DM intake has a significant impact on the milk production by the animals, and consequently on their FE.
For dairy goats, the maximum and minimum fiber contents in the diet to maximize intake and production efficiency are not yet well defined. Carvalho et al. (2006) observed that $27 \%$ of NDF from good-quality forage optimized the dry matter intake and the $3.5 \%$ fat-corrected milk yield.

Linn et al. (2007) observed that increasing the dietary NDF content from 25 to $35 \%$ caused the FE to reduce from 1.7 to 1.4. The results obtained in the present study corroborate those found by the abovementioned authors (Figure 3). This lower intensity in the reduction of FE may be related to the selective behavior of goats compared with cattle.

The digestibility of the dietary DM is closely related to the feed efficiency. According to Reis et al. (2013), among the feeds that compose a diet, the most critical is the roughage. It is of utmost importance that the dairy goat have a balanced diet so that there is no waste of nutrients, especially nitrogen, given that under such conditions the dairy goat can ingest up to $6 \%$ of its body weight.

Unlike grains and other concentrate supplements, roughages have widely variable digestibility values, causing a direct impact on FE. The presence of the nutritional entity called fiber in roughages is characterized by its slow degradation in the rumen, or even indigestibility. Because the chemical components of the fiber are part of the plant cell wall, the time necessary to reduce the size of these biological structures depends on the physical action of chewing. Thus, most of the times the fiber shows a low transit rate, increasing the amount of undigested residues that remain in the rumen, which leads to the rumen-fill effect. As a consequence, feeds with a high NDF concentration, such as roughages, may affect intake with reflections on the animal response.

Animals of higher body weight have worse FE, on average 9.4\% lower (Linn et al., 2009). These authors observed that cows with $545 \mathrm{~kg}$ of live weight had a FE of 1.55 , whereas cows with $815 \mathrm{~kg}$ live weight showed a FE of 1.32. This result indicates that animals with a high DMI, which are those with the greatest body weight, tend to have lower FE as compared with lighter animals. This difference is likely the result of the requirement for maintenance, which has a strong influence in the partition of nutrients during lactation (NRC, 2001).

The net requirement for maintenance represents the energy losses associated with vital body processes like muscle activities, protein turnover, active transport and synthesis of enzymes and/or hormones and others. Body weight is one the factors closely related to net energy for maintenance (Searle et al., 1982). 


\section{Conclusions}

The feed efficiency of lactating goats is affected by the correction of the milk fat, dry matter digestibility, dietary fiber content, use of essential oils in the diet, dietary roughage-to-concentrate ratio and body weight. Among these factors, standardizing the milk fat appears to be most efficient in correcting feed intake in lactating goats. For some of these factors, correction implies greater precision in the measurement of feed efficiency.

\section{References}

Branco, R. H.; Rodrigues, M. T.; Silva, M. M. C.; Rodrigues, C. A. F.; Queiroz, A. C. and Araújo, F. L. 2011. Desempenho de cabras em lactação alimentadas com dietas com diferentes níveis de fibra oriundas de forragem com maturidade avançada. Revista Brasileira de Zootecnia 40:1061-1071.

Box, G. E. P. and Cox, D. R. 1964. An analysis of transformations. Journal of the Royal Statistical Society 26:211-234.

Casper, D. P.; Whitlock, L.; Schauff, D.; Jones, D. and Spangler, D. 2004. Feed efficiency is driven by dry matter intake. Journal of Dairy Science 87:462, Abstract 933.

Carvalho, S.; Rodrigues, M. T.; Branco, R. H. and Rodrigues, C. A. F. 2006. Consumo de nutrientes, produção e composição do leite de cabras da raça Alpina alimentadas com dietas contendo diferentes teores de fibra. Revista Brasileira de Zootecnia 35:1154-1661.

Felisberto, N. R. O. 2011. Tamanho da particula da forragem em dietas para cabras leiteiras. Tese (D.Sc.). Universidade Federal de Viçosa, Viçosa, MG.

Fonseca, C. E. M.; Valadares, R. F. D.; Valadares Filho, S. C.; Leão, M. I. and Marcondes, M. I. 2008. Digestão dos nutrientes e balanço de compostos nitrogenados em cabras alimentadas com quatro níveis de proteína. Arquivo Brasileiro de Medicina Veterinária e Zootecnia 60:192-200.

Gabel, M.; Pieper, B.; Friedel, K.; Radke, M.; Hagemann, A.; Voigt, J. and Kuhla, S. 2003. Influence of nutrition level on digestibility in high yielding cows and effects on energy evaluation systems. Journal of Dairy Science 86:3992-3998.

Henrique, D. S.; Vieira, R. A. M.; Malafaia, P. A. M.; Mancini, M. C. and Gonçalves, A. L. 2005. Estimation of the total efficiency of metabolizable energy utilization for maintenance and growth by cattle in tropical conditions. Revista Brasileira de Zootecnia 34:1006-1016.

Hutjens, M. F. 2005. Dairy efficiency and dry matter intake. p.71-76. In: Proceedings of the 7th Western Dairy Management Conference, Reno, NV.

Hutjens, M. F. 2010. Benchmarking your feed efficiency, feed costs, and income over feed cost. WCDS Advances in Dairy Technology 22:3-10.

Linn, J. 2006. Feed efficiency: Its economic impact in lactating dairy cows. WCDS Advances in Dairy Technology 18:19-28.
Linn, J.; Raeth-Knight, M.; Fredin, S. and Bach, A. 2007. Feed efficiency in lactating dairy cows. p.10. In: Proceedings of the Colorado Dairy Nutrition Conference, Colorado.

Linn, J.; Raeth-Knight, M. and Litherland, N. 2009. Role of feed (dairy) efficiency in dairy management. p.167-176. Proceedings of the 44th Pacific Northwest Animal Nutrition Conference, Boise, Idaho.

Mertens, D. R. 1994. Regulation of forage intake. p.450-493. In: Forage quality, evaluation, and utilization. Fahey Junior, G. C.; Collins, M. and Mertens, D. R., eds. American Society of Agronomy, Crop Science Society American, and Soil Science Society of America, Madison.

Mertens, D. R. 1997. Creating a system for meeting the fiber requirements of dairy cows. Journal of Dairy Science 80:1463-1481.

Mood, A. M.; Graybill, F. A. and Boes, D. C. 1974. Introduction to the theory of statistics. 3rd ed. McGraw-Hill Book Co., New York.

NRC - National Research Council. 2001. Nutrient requirements of dairy cattle. 7th ed. National Academy, Washington.

Oliveira Junior, R. C.; Susin, I.; Pires, A. V.; Simas, J. M. C. and Morais, J. B. 2002. Desempenho de cabras em lactação alimentadas com grão de soja. Acta Scientiarum 24:1113-1118.

Reis, R. B. and Sousa, B. M. 2013. Nutrição de bovinos sob a perspectiva ambiental do balanço de nutrientes. p.41-76. In: Anais do 2o Simpósio Brasileiro de Produção de Ruminantes no Cerrado: Inovações Tecnológicas. Macedo Junior, G. L.; Santos, M. E. R.; Barbero, L. M.; França, J. and Ferreira, I. C., eds. FAMEV-UFU, Uberlândia.

Searle, T. W.; Graham, N. M. C. and Donnelly, J. B. 1982. The effect of plane of nutrition on the body composition of two breeds of weaner sheep fed a high protein diet. Journal Agricultural Science 98:241-245

Sklan, D.; Ashkenaz, R.; Braun, A.; Devorin, A. and Tabori, K. 1992. Fatty acids, calcium soaps of fatty acids, and cottonseeds fed to high yielding cows. Journal of Dairy Science 75:2463-2472.

Silva, J. H. V.; Rodrigues, M. T. and Campos, J. 1999. Desempenho de cabras leiteiras recebendo dietas com diferentes relações volumoso: concentrado. Revista Brasileira de Zootecnia 28:1412-1418.

Silva, M. M. C. 2005. Suplementação de lipídios em dietas para cabras leiteiras. Tese (D.Sc.). Universidade Federal de Viçosa, Viçosa, MG.

Socha, M. T.; Tomlinson, D. J. and Defrain, J. M. 2007. Measuring and improving feed efficiency in lactating dairy cows. p.235-246. In: Proceedings of the Intermoutain Nutrition Conference, Salt Lake City.

St-Pierre, N. R. 2001. Economic factors affecting nutrient balance on dairy farms. Advances in Dairy Techonology 13:263-281.

Zambom, M. A.; Alcalde, C. R.; Silva, K. T.; Macedo, F. A. F.; Santos, G. T.; Borghi, E. L. and Barbosa, E. D. 2005. Ingestão, digestibilidade das rações e produção de leite em cabras saanen submetidas a diferentes relações volumoso:concentrado na ração. Revista Brasileira de Zootecnia 34:2505-2514.

Zambom, M. A.; Alcalde, C. R.; Silva, K. T.; Macedo, F. A. F.; Ramos, C. E. C. O. and Passianoto, G. O. 2008. Desempenho e digestibilidade dos nutrientes de rações com casca do grão de soja em substituição ao milho para cabras Saanen em lactação e no préparto. Revista Brasileira de Zootecnia 37:1311-1318. 